\title{
Vegetable Marketing by Nilgiris Cooperative Marketing Society - A Paradigm
}

\author{
C. Sekhar*, A. Vidhyavathi and A. Divakaran \\ Department of Agricultural Economics, Tamil Nadu Agricultural University, \\ Coimbatore - 641 003, India \\ *Corresponding author
}

\begin{tabular}{|l|}
\hline Ke y w o r d s \\
$\begin{array}{l}\text { Niligiris cooperative } \\
\text { marketing society, } \\
\text { Production and } \\
\text { distribution, Fertilizers } \\
\text { and chemicals, } \\
\text { Performance of NCMS }\end{array}$ \\
\hline Article Info \\
\hline $\begin{array}{l}\text { Accepted: } \\
\text { 12 July 2019 } \\
\text { Available Online: } \\
\text { 10 August } 2019\end{array}$ \\
\hline
\end{tabular}

A B S T R A C T
Nilgiris Cooperative Marketing Society was established during the year 1935 by the progressive farmer "Auri Gowder" who was keen in developing the society by getting the support of fellow farmers and the society has diversified its activities in the present scenario and capable of fetching a net profit to the tune of Rupees 234 lakhs per annum on an average. Though it deals with different hill vegetables, Potato found to dominate among the vegetable category and these vegetables are being distributed through the Society by way of auctioning the commodity by inviting the registered traders. The average price received by the farmers for Potato vegetable was found to be Rs 17 per $\mathrm{kg}$ and the other vegetables were priced at Rs 22 per kg revealed that the farmers are receiving a considerable share. Besides these, the NCMS is involved in production and distribution of crop specific complex fertilizers from its fertilizer mixing unit. Among the crop specific fertilizers, Tea and the Potato vegetables gained higher number of branded fertilizers of NPK. In addition to the services, the NCMS is also providing pledge loan and distribution of Liquid Petroleum Gas to the farm households and thereby permitting the pollution free environment.

\section{Introduction}

Agricultural Marketing is the study of all the operations involved and agencies responsible in conducting the business which involves the movement of farm produce like fruits and vegetables and other food grains from the production zone (Farm) to the ultimate consumers (Fork) and the effects of such operations on farmers, middlemen and consumers. The National Commission on
Agriculture (1976) has defined agricultural marketing as a process which starts with a decision to produce a saleable farm commodity and it involves all aspects of market structure of the system, both functional and institutional, based on technical and economic considerations and includes pre and post-harvest operations, assembling, grading, storage, transportation and distribution. Agricultural marketing thus is the study of all the activities, agencies and policies involved 
in the procurement of farm inputs by the farmers and the movement of agricultural products from the farmers to the ultimate consumers. Since the interference of too many middlemen in the marketing process of farm grown commodities, the farmers were unable to realize considerable profit from the production and distribution system and hence the farmers themselves has joined together had established a system to market their produce known as Cooperative marketing.

Trade liberalization and globalization are market trends that push for cooperative efforts in vegetable marketing. Liberalization of agricultural trade should not be regarded as an end itself. It should only be involved to improve the functioning of agricultural markets, increase farm incomes, eradicate poverty and promote socially and environmentally sustainable programs. Given the fact that agriculture in Asia Pacific region is usually carried out by family members. It is their belief that more than ever they need to strengthen cooperative relationships to protect members' interest in the light of WTO agreements (Manalili, 2003)

Cooperation in marketing of farm produce is a business type to take a fair price system by selling the produce directly to the retailers or consumers so as to gain considerable profit. Cooperative market is a voluntary business organization established by its member to market farm products collectively for their benefit. The members of the cooperative marketing organization are the owners of the farm, operators and contributors of the commodities handled are the direct beneficiaries of the savings that may accrue. Cooperative marketing is an extension of the philosophy and principles of cooperation in the area of agricultural or horticultural marketing. It is a process of marketing through a cooperative society formed voluntarily for the producers, by the producers to perform one or more marketing functions in respect of their produce and seeks to eliminate the middlemen between the producers and the consumers, thus getting the reasonable price for their produce. But the cooperative marketing system is facing troubles in its performance due to the interruption of socio-political system and the true spirit of cooperation could not be ensured and faces loss of many cooperative institutions.

A working group on Outreach of Institutional Finance and Cooperative Reforms for Eleventh Five Year Plan (2007-2012) had reviewed the status of cooperatives and its role in the economic development of the country, by identifying the factors inhibiting the development of cooperatives; suggest measures for human resource development in cooperatives of agricultural sector. The group had suggested various programs, schemes and strategic reforms in cooperative sector for the eleventh five year plan to address the agricultural growth and its distress.

In Tamil Nadu, the Cooperative marketing societies have been established with the object of facilitating the marketing of farm produce of its members at a remunerative price besides distributing the need based farm inputs through the society, providing pledge loan facility on agricultural produce and undertaking the processing and value addition to the farm produce handled. The structure of Cooperative marketing in Tamil Nadu is of two tier structure with the Tamil Nadu Cooperative Marketing Federation (TANFED) at apex level and Primary Agricultural Marketing Societies at district or taluk levels. Besides these, there are three special types of cooperative marketing societies such as The Nilgiris Cooperative Marketing Society (NCMS) based at Ooty, The Nilgiris; Thanjavur Cooperative Marketing Federation and Tudiyalur Cooperative Agricultural Services Society (TUCAS) are also working 
apart from TANFED and cooperative marketing societies. In this circumstance, how the special type of cooperative societies particularly the NCMS is serving the farming community through its diversification of activities and its performance with respect to profit generation from various business activities becomes important and hence this paper is aimed at addressing the overall performance of NCMS.

\section{Materials and Methods}

\section{Design of the study}

Nilgiris Cooperative Marketing Society (NCMS) is a special type of cooperative marketing society established at Ooty to facilitate the farmers in marketing their produce and release them from the clutches of middlemen who lend the small money for agricultural activity and force the farmers to surrender their produce to them at poor price and hence the farmers were unable to get a good return and hence the society was established during the year 1935 by the architect and founder of the society, named "Auri Gowder" (Table 1). The society is taken as a case study for the present research to assess the performance of cooperative marketing society.

The commencement of activities of the society was from $20^{\text {th }}$ December 1935. Currently, the Nilgiris Cooperative Marketing Society has 26239 members. The share capital of the members were arrived at 9.73 lakhs and the permitted share value is around 50 lakhs. The head office of NCMS is based at Ooty and the branch office is located at Mettupalayam of Coimbatore District to regulate the distribution of hill vegetables throughout Southern India. Though the society was established exclusively for the purpose of marketing of vegetables and to meet the financial implications that arose to the farming community in the Nilgiris, it has diversified its activities over a period of time and has the mission activities in a planned and phased manner. These are described in Table 2.

The multifarious activities of the society are outlined in Table 2. Around 10 activities were considered as important and are being performed in a better way. Among the various activities, marketing of vegetables, production and distribution of fertilizers and pledge loan provision were the important activities which are directly useful to the farming community. No other cooperative societies had such multiple activities and hence special emphasis was given to select the society to assess its performance in all quartz following a case study approach. The case study has considered the General Manager of the Society as its principal respondent and the Chief Accountant of the Society as another respondent to document the production and financial performance and the details were gathered from their records and their experiences in running the society has also been shared and the details were analysed using simple percentage analysis and the details are presented in different headings.

\section{Results and Discussion}

Cooperative Marketing was gaining importance in India a decade before and in some places, the performance of cooperatives were found to be promising due to the participation of members and the efforts taken up by the officers concerned in running the society. Though it had several activities, there were certain core activities which are earmarked and are capable of fetching laurel to the society. The Nilgiris Cooperative Marketing Society have one such principal activity which is spelt as "Marketing of Vegetables produced by the farmers and Production and distribution of crop specific fertilizer mixtures by deciding the appropriate mix of Nitrogen, Phosphorous and Potash based on the recommendations. Before 
entering into the aspects of core activities, the status of vegetable production in the Nilgiris District is an important one and hence these results are analysed and are suitably presented in Table 3.

The Nilgiris district is occupying highest area under Plantation Crops in an area of 64383 ha which is accounted for 89.72 per cent to the total area under different crops followed by vegetable crops occupied an area of 4099 ha which is accounted for 5.71 per cent to the total (Table 3). The area under spices and condiments is arrived at 3.56 per cent to the total area. It is interesting to observe that the area under flowers, medicinal and aromatic crops were found to have poor area that too in a double and single digit called for area expansion programs under these crops. Since Nilgiris is famous for conducting flower show, the area under flower crops was given poor attention. The climate of Nilgiris is a good one for cultivating variety of Roses and other ornamental flowers for export, the area under flowers need to be given much importance.

\section{Marketing of Vegetables Produced by the Farmers of Nilgiris}

Marketing of vegetable being the principal activity to NCMS, the details of quantity transacted in respect of potatoes and other vegetables like carrot, beetroot and beans including Garlic were analysed and the details are presented in Table 4.

The quantity of potatoes marketed through NCMS presented in Table 4 is arrived at $14622 \mathrm{kgs}$ per annum which has generated the value of sales to the tune of 2501 lakhs annually with an average price of Rs 17.11 per $\mathrm{kg}$. On the day of conduct of case study scheduled on $10^{\text {th }}$ July 2019 , the price of potato per $\mathrm{kg}$ was arrived at $\mathrm{Rs} 55$ and the retail price was found to be in the range of Rs 65 to Rs 70 in different locations of Tamil
Nadu for the Ooty Potatoes. Whereas, the potatoes received from other places were priced at Rs 25 to Rs 30 in different locations. These potatoes were supplied from Kolar District of Karnataka. In respect of other vegetables, Carrot, Beetroot, Beans and Garlic Spice have also been included and their total transactions per annum is arrived at 4749 tonnes which had generated the sale value of Rs 1065.96 lakhs per annum. The average price prevailed per annum is arrived at Rs 22.45 per $\mathrm{kg}$. From that one could infer that the Carrot, Beetroot, Beans has generated an average price of Rs. 18.42 per $\mathrm{kg}$. But the prices of Carrot and Beans even have touched the peak of Rs 60 to 80 in some of the season due to its poor production and supply of hill vegetables. More than 20 per cent of Nilgiris District vegetable production is marketed through NCMS. Hence the Nilgiris Cooperative Marketing Society can have its own linkages with the Domestic and Export Market Intelligence Cell (DEMIC) operated in the Department of Agricultural Economics of Tamil Nadu Agricultural University, Coimbatore to learn the forecast prices and the same can be advocated to the farmers who are cultivating the hill vegetables so as to balance the production and supply situation in Tamil Nadu and other parts of India.

According to Manalili (2003), 44 per cent of the respondents have not known about the successful cooperatives and those who did (21 per cent) considered Kapatagon Livelihood Integrated Development Cooperative as a successful cooperative. Any cooperative society to be successful, the Managing Director or the Special Officer attached to the society and his vision based leading will alone take the society to new heights.

Using a Theoretical model, direct selling and marketing through a cooperative might be beneficial for each other. Indeed, the cooperative, by proposing a unique price and 
uniform profit sharing allows farmers to collude on the local market making them softer competitors on that market. When a farmer increases the quantity he sells to the cooperative, he becomes less aggressive on the local market. Thus, the cooperative can have an anti-competitive effect on direct selling market and benefit farmers. Conversely, the direct selling characterized by an oligopolistic market structure can create a healthy emulation and incite farmers to increase production that benefit the cooperatives. In certain cases, all the farmers are not turning towards cooperative fold. Some leakages are visible and hence the NCMS can think of entering some possible tripartite or quadripartite arrangements between NCMS, supermarkets and their preferred suppliers.

\section{Production and Distribution of Fertilizers and Chemicals}

Another important activity of Nilgiris Cooperative Marketing Society is production and distribution of fertilizers and chemicals which are essentially needed to the farmers who are capable of producing the hill vegetables like Carrot, Beetroot, Beans and Potatoes. Besides these, the farmers were also producing Turnip, Garlic Spice in considerable quantity and hence the need of inputs by the farmers are more and hence the NCMS has specially committed themselves in the process of production and distribution of fertilizers and chemicals and hence these details were analysed and the results are presented in Table 5.

Table 5 outlined that the fertilizer production per annum was arrived at 13029 tonnes. The average price of fertilizer sold by the NCMS per $\mathrm{kg}$ was arrived at Rs 13/- and the value of fertilizers sold by the NCMS was arrived at 1704 lakhs per annum. The output produced was distributed to different demanding centres within the Nilgiris and Coimbatore Districts. Another important input is production of Pesticides and Chemicals for the control of weeds, insects and diseases of different hill vegetables and hence NCMS is also concentrating on selling of Pesticides and Chemicals by obtaining the same from leading manufacturers and are sold at below the market price offered for such chemicals and pesticides and hence the farmers were found useful to enhance the production of vegetables without any interference. However, the fertilizer production in different brands was made because of the erection of fertilizer mixing unit with the NCMS. With the support of mixing unit, the NCMS is producing appreciable quantity of fertilizer mix used for different crops and hence these details are analysed and the results are presented in Table 6.

Table 6 outlined that the average quantity of fertilizer mixturesof different brands produced and marketed was at 3637 tonnes per annum and the same is accounted for 28 per cent to the total quantity of fertilizer produced by the Nilgiris Cooperative Marketing Society, Ooty. The peak production was arrived at 6592 tonnes during the year 2017-18 which is respectively accounted for 35.45 per cent to the total quantity of fertilizer produced during the year 2017-18.

Whatever the quantity produced are sold out and it has generated an average sales value of 531 lakhs per annum and the average price of the mixed fertilizer is arrived at Rs 14600/Besides these, NCMS is also procuring seeds of Cabbage, Carrot, Beetroot, Beans and Potatoes from the leading producers of seeds and are appropriately distributed to the farmers for enhancing the production and productivity of hill vegetables. NCMS is supplying vegetable seeds at a price which is lesser than the market price of vegetable seeds. 


\section{Production of complex fertilizers}

Unlike straight fertilizers, complex fertilizers are presently used for different crops. Different crops have different level of consumption of fertilizers and hence the absolute requirement of fertilizers like Nitrogen, Phosphorous and Potash (NPK) are appropriately mixed based on the recommendations of the crop production guide and the fertilizers are appropriately mixed and are branded suitably to promote the sales of complex fertilizers. The list of mixed crop specific fertilizers is presented in Table 7.

Table 7 revealed the details of different combinations of NPK mix for different crops. The Tea plantations have four different fertilizer combinations to meet the different soil requirements in Ooty.

The complex fertilizers developed for Tea is bearing the identification numbers 12, 16, 26 and 27 which is respectively developed with the NPK combinations specially viz., $16: 00$ : $12 ; 20: 00: 10 ; 26: 00: 26$ and $21: 00: 32$.

From this ratio, one could examine the absence of Phosphoric fertilizers due to the abundance of Phosphorous in the native soils. For the plantations of Tea and Coffee another category of complex fertilizer developed is branded with 24 identification number which has 20: 06: 10 of NPK combinations.

Potato is the principal vegetable cultivated in Ooty which had attracted two different combinations of complex fertilizers with the NPK combinations in the order of 06:12: 06 and 17:17: 17 to suit the soils and to enhance the productivity of Potato in the Nilgiris. The 17: 17: 17 combination was also recommended for other vegetables like Cabbage, Carrot, Beans and Turnip. In general, the vegetable crops had attracted the NPK combinations in the order of 09: 09: 09.

\section{Distribution of pledge loan to the farmers of Nilgiris}

To apply various inputs in the production process, the farmers are in need of investment. Since most of the farmers are having one to two acres of land, they are facing financial problems to carry out the agricultural operations, they seek the financial assistance from the money lenders and traders. In Traditional Marketing Systems, the producers or growers often receive the financial support from Traders (Vidhyavathi et al., 2012).

Since the money lenders and traders are following a threatened approach and make the farmer to an indebted situation, the NCMS has come forward to provide the pledge loan facilities to the farmers and hence these details are analysed and the results are presented in Table 8.

Table 8 revealed that the average distribution of gold loan or pledge loan to the farmers was arrived at Rs 1892 lakhs per annum. When we examine the average loan received by the farmer with respect to the membership of the society, it is arrived at Rs. 7278 per annum which is a considerable amount for taking up of cultivation activities.

However, the recovery from each farmer at the end of harvest of crops needs to be intensified. In this respect, an amount of Rs 1248 lakhs of Rupees is an outstanding amount pending from the farmers and the same is accounted to be Rs 4802 per farmer per annum.

However, the issue of pledge loan during the year 2014-15 found to be the maximum and later on, the amount issued under the head is found to be decreasing. It might be due to the less demand among the farmers in availing the loan facility or the farmer once pledged unable to be recovered fully might be the reason for such decrease. 
Table.1 General particulars of the marketing society

\begin{tabular}{|c|l|l|}
\hline Sl. No & \multicolumn{1}{|c|}{ Particulars of NCMS } & \multicolumn{1}{|c|}{ Details of Establishment } \\
\hline $\mathbf{0 1}$ & Date of Registration of the Society & $8^{\text {th }}$ December 1935 \\
\hline $\mathbf{0 2}$ & Registration Number & K-708 \\
\hline $\mathbf{0 3}$ & Date of Commencement of the Society & 20 $0^{\text {th }}$ December 1935 \\
\hline $\mathbf{0 4}$ & Name of the Founder of the Society & Mr. Rao Bahadur Auri Gowder \\
\hline $\mathbf{0 5}$ & Permitted Value of the Shares & Rs. 50 Lakhs \\
\hline $\mathbf{0 6}$ & Share Capital of the Members & 09.73 Lakhs \\
\hline $\mathbf{0 7}$ & Number of Members of the Society & 26239 \\
\hline $\mathbf{0 8}$ & Jurisdiction of the Society & $\begin{array}{l}\text { Nilgiris District and the Mettupalayam } \\
\text { Town of Coimbatore District }\end{array}$ \\
\hline
\end{tabular}

Table. 2 The details of activities undertaken by the marketing society (NCMS)

\begin{tabular}{|c|l|}
\hline Sl. No & \multicolumn{1}{|c|}{ Details of Activities } \\
\hline $\mathbf{0 1}$ & Marketing of Vegetables Produced by the Farmers of Nilgiris District \\
\hline $\mathbf{0 2}$ & Production and Distribution of Crop Specific Fertilizers and Chemicals \\
\hline $\mathbf{0 3}$ & Fertilizer Mixing Unit to meet the Requirements of Different Vegetable Crops \\
\hline $\mathbf{0 4}$ & Distribution of Jewel Pledge Loan to the Farmers of Nilgiris \\
\hline $\mathbf{0 5}$ & Distribution of Kerosene to the Farmers Through Public Distribution System \\
\hline $\mathbf{0 6}$ & Distribution of Liquid Petroleum Gas to the Farmers \\
\hline $\mathbf{0 7}$ & Vehicle Parking Facility for the Tourists \\
\hline $\mathbf{0 8}$ & Computerized Weigh Bridge Services \\
\hline $\mathbf{0 9}$ & Providing Community Hall Services to the Farmers \\
\hline $\mathbf{1 0}$ & Overall Performance of the Nilgiris Cooperative Marketing Society \\
\hline
\end{tabular}

Table.3 Area production and productivity of vegetables in Nilgiris District (2017-18)

\begin{tabular}{|r|l|c|c|c|}
\hline $\begin{array}{r}\text { Sl. } \\
\text { No }\end{array}$ & Name of the Crops & Area in Ha & $\begin{array}{c}\text { Production in } \\
\text { Tonnes }\end{array}$ & $\begin{array}{c}\text { Productivity in } \\
\text { Tonnes per Ha }\end{array}$ \\
\hline $\mathbf{0 1}$ & Fruits & $0667(00.93)$ & 13904 & 20.85 \\
\hline $\mathbf{0 2}$ & Vegetables & $4099(05.71)$ & 96714 & 23.59 \\
\hline $\mathbf{0 3}$ & Plantation Crops & $64383(89.72)$ & 540544 & 08.40 \\
\hline $\mathbf{0 4}$ & Spices and Condiments & $2556(03.56)$ & 11255 & 04.40 \\
\hline $\mathbf{0 5}$ & Flowers & $0056(00.08)$ & 2498 & 44.61 \\
\hline $\mathbf{0 6}$ & $\begin{array}{l}\text { Medicinal and Aromatic } \\
\end{array}$ & $02.50(00.001)$ & 0030 & 12.00 \\
\hline & & & 664945 & 09.27 \\
\hline
\end{tabular}

(Figures in Parenthesis indicate Percentage to Total Area under Different Crops)

(Source: Department of Horticulture and Plantation Crops, Ooty) 
Table.4 Marketing of vegetables produced by the farmers of Nilgiris District

\begin{tabular}{|c|c|c|c|c|c|c|}
\hline \multirow{2}{*}{ Year } & \multicolumn{2}{|c|}{ Potatoes } & \multicolumn{2}{c|}{$\begin{array}{c}\text { Other Vegetables } \\
\text { including Garlic }\end{array}$} & \multicolumn{2}{c|}{ Total Vegetables } \\
\cline { 2 - 7 } & $\begin{array}{c}\text { Quantity Sold in } \\
\text { Tonnes }\end{array}$ & $\begin{array}{c}\text { Sale Value } \\
\text { in Lakhs }\end{array}$ & $\begin{array}{c}\text { Quantity Sold } \\
\text { in Tonnes }\end{array}$ & $\begin{array}{c}\text { Sale Value } \\
\text { in Lakhs }\end{array}$ & $\begin{array}{c}\text { Quantity Sold } \\
\text { in Tonnes }\end{array}$ & $\begin{array}{c}\text { Sale Value } \\
\text { in Lakhs }\end{array}$ \\
\hline $\mathbf{2 0 1 1 - 1 2}$ & 17082 & 1862.67 & 1473 & 281.00 & 18555 & 2143.67 \\
\hline $\mathbf{2 0 1 2 - 1 3}$ & 12418 & 2001.54 & 1898 & 318.80 & 14316 & 2320.34 \\
\hline $\mathbf{2 0 1 3 - 1 4}$ & 17029 & 3090.57 & 22276 & 3449.84 & 39305 & 6540.41 \\
\hline $\mathbf{2 0 1 4 - 1 5}$ & 17986 & 4006.82 & 2095 & 748.56 & 20081 & 4755.38 \\
\hline $\mathbf{2 0 1 5 - 1 6}$ & 18127 & 2795.67 & 1785 & 928.97 & 19912 & 3724.64 \\
\hline $\mathbf{2 0 1 6 - 1 7}$ & 08650 & 1553.90 & 3590 & 1253.66 & 12240 & 2807.56 \\
\hline $\mathbf{2 0 1 7 - 1 8}$ & 12297 & 1995.58 & 2646 & 817.81 & 14943 & 2813.39 \\
\hline $\mathbf{2 0 1 8}-19$ & 13385 & 2703.21 & 2229 & 729.07 & 15614 & 3432.28 \\
\hline Average & 14621.750 & 2501.25 & 4749 & 1065.96 & 19370.750 & 3567.21 \\
\hline Average Price per Kg (Rs) & 17.11 & & 22.45 & & 18.42 \\
\hline \multicolumn{7}{|c|}{ Average Price of Potatoes per Kg on 10 } \\
\hline
\end{tabular}

Table.5 Production and distribution of crop specific fertilizers and chemicals

\begin{tabular}{|c|c|c|c|c|}
\hline \multirow{2}{*}{ Year } & \multicolumn{2}{|c|}{ Fertilizers } & \multirow{2}{*}{$\begin{array}{l}\text { Value of Pesticides } \\
\text { Sold in Lakhs }\end{array}$} & \multirow{2}{*}{$\begin{array}{c}\text { Value of Farm } \\
\text { Implements Sold in } \\
\text { Lakhs }\end{array}$} \\
\hline & Quantity in Tonnes & $\begin{array}{c}\text { Value in } \\
\text { Lakhs }\end{array}$ & & \\
\hline 2014-15 & 11225 & 1521.53 & 70.93 & 120.91 \\
\hline 2015-16 & 9544 & 1281.38 & 86.83 & 42.63 \\
\hline 2016-17 & 15997 & 2079.94 & 136.01 & 62.77 \\
\hline 2017-18 & 18595 & 2304.78 & 230.99 & 86.98 \\
\hline 2018-19 & 9784 & 1334.13 & 73.36 & 77.39 \\
\hline Average & $13029(13.08)$ & 1704.35 & 119.62 & 78.14 \\
\hline
\end{tabular}

(Figures in Parenthesis indicate Average Price of Fertilizer per Kg)

Table.6 Production of complex fertilizers through the fertilizer mixing unit

\begin{tabular}{|c|c|c|c|}
\hline Year & $\begin{array}{c}\text { Production of Fertilizers in } \\
\text { Tonnes }\end{array}$ & $\begin{array}{c}\text { Quantity of Fertilizers } \\
\text { Sold in Tonnes }\end{array}$ & $\begin{array}{c}\text { Value of Fertilizers } \\
\text { Sold in Lakhs }\end{array}$ \\
\hline $\mathbf{2 0 1 4 - 1 5}$ & 546.000 & 546.000 & 68.80 \\
\hline $\mathbf{2 0 1 5 - 1 6}$ & 4311.000 & 4311.000 & 689.76 \\
\hline $\mathbf{2 0 1 6 - 1 7}$ & 4204.000 & 4204.000 & 604.03 \\
\hline $\mathbf{2 0 1 7 - 1 8}$ & 6592.500 & 6592.500 & 908.96 \\
\hline $\mathbf{2 0 1 8 - 1 9}$ & 2532.000 & 2532.000 & 383.50 \\
\hline Average & $\mathbf{3 6 3 7 . 0 0 0}(\mathbf{2 7 . 9 1 )}$ & $\mathbf{3 6 3 7 . 0 0 0}$ & $\mathbf{5 3 1 . 0 1}$ \\
\hline & Average Price per Ton of Fertilizers in Rupees & $\mathbf{1 4 6 0 0 . 2 2}$ \\
\hline
\end{tabular}

(Figures in Parenthesis indicate Percentage of Fertilizer Mixing to the Total Outturn of Fertilizers per annum) 
Table.7 Complex fertilizer production for the requirements of different vegetable crops

\begin{tabular}{|c|l|c|c|}
\hline SI. No & \multicolumn{1}{|c|}{ Name of the Crop } & $\begin{array}{c}\text { Fertilizer Identification } \\
\text { Number }\end{array}$ & $\begin{array}{c}\text { Complex Fertilizer } \\
\text { Ratio (N: P: K) }\end{array}$ \\
\hline $\mathbf{0 1}$ & Potato and other Vegetables & 04 & $06: 12: 06$ \\
\hline $\mathbf{0 2}$ & Vegetables & 05 & $09: 09: 09$ \\
\hline $\mathbf{0 3}$ & Tea & 12 & $16: 00: 12$ \\
\hline $\mathbf{0 4}$ & Tea & 16 & $20: 00: 10$ \\
\hline $\mathbf{0 5}$ & Potato & 18 & $17: 17: 17$ \\
\hline $\mathbf{0 6}$ & Tea and Coffee & 24 & $20: 06: 10$ \\
\hline $\mathbf{0 7}$ & Tea & 26 & $26: 00: 26$ \\
\hline $\mathbf{0 8}$ & Tea & 27 & $21: 00: 32$ \\
\hline
\end{tabular}

Table.8 Distribution of jewel pledge loan to the farmers of Nilgiris

\begin{tabular}{|c|c|c|c|}
\hline SI. No & Year & $\begin{array}{c}\text { Amount of Pledge Loan } \\
\text { Issued in Lakhs }\end{array}$ & $\begin{array}{c}\text { Balance Amount at the } \\
\text { End of the Year in } \\
\text { Lakhs }\end{array}$ \\
\hline $\mathbf{0 1}$ & $2014-15$ & 2208.74 & 1560.43 \\
\hline $\mathbf{0 2}$ & $2015-16$ & 1957.59 & 1118.84 \\
\hline $\mathbf{0 3}$ & $2016-17$ & 1873.57 & 1274.05 \\
\hline $\mathbf{0 4}$ & $2017-18$ & 1704.66 & 1174.73 \\
\hline $\mathbf{0 5}$ & $2018-19$ & 1716.30 & 1114.67 \\
\hline & Average & $\mathbf{1 8 9 2 . 1 7}$ & $\mathbf{1 2 4 8 . 5 4}$ \\
\hline
\end{tabular}

Table.9 Distribution of kerosene and LPG to the farmers

\begin{tabular}{|c|c|c|c|}
\hline Sl. No & Year & $\begin{array}{c}\text { Value of Kerosene } \\
\text { Distributed in Lakhs }\end{array}$ & $\begin{array}{c}\text { Number of LPG } \\
\text { Connections Provided }\end{array}$ \\
\hline $\mathbf{0 1}$ & $2014-15$ & 28.81 & $\begin{array}{c}\text { 9580 } \\
\text { (During September 2000 } \\
\text { to March 2019) }\end{array}$ \\
\hline $\mathbf{0 2}$ & $2015-16$ & 26.18 & \\
\hline $\mathbf{0 3}$ & $2016-17$ & 17.23 & \\
\hline $\mathbf{0 4}$ & $2017-18$ & 07.22 & 504.21 \\
\hline $\mathbf{0 5}$ & $2018-19$ & 07.00 & \\
\hline
\end{tabular}


Table.10 Income earned through vehicle parking facility and community hall

\begin{tabular}{|c|c|c|c|}
\hline Sl. No & Year & $\begin{array}{c}\text { Income Earned through } \\
\text { Vehicle Parking in Rupees }\end{array}$ & $\begin{array}{c}\text { Income Earned through } \\
\text { Community Hall }\end{array}$ \\
\hline $\mathbf{0 1}$ & $2014-15$ & 1941760.00 & NA \\
\hline $\mathbf{0 2}$ & $2015-16$ & 2307428.00 & NA \\
\hline $\mathbf{0 3}$ & $2016-17$ & 2297850.00 & 622600.00 \\
\hline $\mathbf{0 4}$ & $2017-18$ & 2264288.00 & 887500.00 \\
\hline $\mathbf{0 5}$ & $2018-19$ & 1158470.00 & 621500.00 \\
\hline & Average & 1993959.20 & 710533.33 \\
\hline
\end{tabular}

Table.11 Profit earned by the Nilgiris Cooperative Marketing Society over the years

\begin{tabular}{|c|c|c|c|}
\hline Sl. No & Year & $\begin{array}{c}\text { Profit Earned through } \\
\text { Different Activities in Lakhs }\end{array}$ & Status of Audit \\
\hline $\mathbf{0 1}$ & $2010-11$ & 74.30 & Audited \\
\hline $\mathbf{0 2}$ & $2011-12$ & 82.74 & Audited \\
\hline $\mathbf{0 3}$ & $2012-13$ & 90.82 & Audited \\
\hline $\mathbf{0 4}$ & $2013-14$ & 301.86 & Audited \\
\hline $\mathbf{0 5}$ & $2014-15$ & 255.19 & Audited \\
\hline $\mathbf{0 6}$ & $2015-16$ & 210.67 & Audited \\
\hline $\mathbf{0 7}$ & $2016-17$ & 390.76 & Audited \\
\hline $\mathbf{0 8}$ & $2017-18$ & 154.18 & To be Audited \\
\hline Average Profit in Lakhs per Annum & 233.91 & \\
\hline
\end{tabular}

Table.12 The Future Plan of Expansion Programs with NCMS

\begin{tabular}{|c|l|}
\hline Sl. No & Future Programs of Nilgiris Cooperative Marketing Society \\
\hline $\mathbf{0 1}$ & Proposal Sent to the Government to become the Dealer of Arasu Cement \\
\hline $\mathbf{0 2}$ & Proposal Sent to the Government to Erect the Indian Oil Corporation Petrol Bunk \\
\hline $\mathbf{0 3}$ & Establishment of New Branches of NCMS for Extending Pledge Loan Facility \\
\hline $\mathbf{0 4}$ & Establishment of New Branches of NCMS for Fertilizer Distribution Units \\
\hline
\end{tabular}

Distribution of kerosene and LPG to the farmers

The farm households were utilizing the fuel wood for their cooking and heating purposes before a decade of time. The NCMS has thought of reducing the smoke that arose from the households and hence started using the kerosene as one of the fuel for cooking and heating purposes and later on the availability of Liquid Petroleum Gas to the farm households become normalized and hence the people started using the liquid petroleum gas as their fuel for cooking and heating purposes. In this respect, the extent of supply of kerosene and liquid petroleum gas details were collected and the results are presented in Table 9.

Table 9 revealed that the value of supply of kerosene by NCMS from the year 2014-15 is found to be 28.81 lakhs and the same was during the year 2018-19 was arrived at Rs. 7 lakhs. The reduction in the value of supply of 
Kerosene in the farm households was found to be 76 per cent during the year 2018-19 over the base period of 2014-15. This reduction might be due to the increased usage of Liquid Petroleum Gas among the farm households. About two decades of time (2000 - 2019), the LPG connections were given to the tune of 9580 connections and the average connection per annum is arrived at 504 numbers revealed that the farm households were increasingly demanding the LPG connections for their home for cooking and heating purposes, thereby an environmental pollution is prevented in the virgin forest areas.

\section{Income generation by NCMS through other activities}

The other activities of NCMS are provision of vehicle parking facility and extending the services of community hall for performing social functions. From these facilities the NCMS is generating considerable return viz. Rs 150 for buses, Rs. 100 for Van type vehicles and Rs 50 for Jeep and Cars per day and hence the income generation were analysed over the years and the results are presented in Table 10.

The average income generated by NCMS from the facility of vehicle parking was found to be 19.94 lakhs (Table 10) and the income generated from the community hall facility was arrived at Rs. 7.11 lakhs per annum.

From that one could infer that the rental service of community hall is extended to limited numbers or the service was not much demanded among the consumers or the farm households at Ooty.

In this circumstance, the NCMS can lend the hall for other shows like conducting book exhibition, agricultural exhibition, and value added products, fruits produced from Ooty may be organized to generate higher return.

\section{Profit earned by the Nilgiris cooperative marketing society}

Through its various vibrant activities, the society is capable of earning considerable income and hence effort has been taken to assess the profit retained by the society over the years becomes important and hence these details are analysed and the results are presented in Table 11.

The average profit earned by the NCMS in an eight years period of time was assessed as 234 lakhs after meeting the costs of various items including salaries to the staff members of the society (Table 11). When one could examine the profit over the years, 2013-14 and 201617 were found to be the good years to achieve highest profit in an eight years period of time. The year 2016-17 was able to generate the highest profit of around 391 lakhs. It might be due to the good crop year, good yield and attractive prices to the farm produce produced at Ooty hills and hence the Registrar of Cooperative Societies of Tamil Nadu can launch a scheme to evaluate the society activities and can examine the ways and means of promoting higher profit by diversifying the activities of NCMS further.

\section{Future plan and programs of NCMS}

Business expansion is normally centred on two main facts. Number one is diversification of need based activities in the society, and another is at a minimum cost operations maximizing the return from the produce by identifying the potential market and its demand and its price offered at the particular day or the week are of much importance to the manager operating the society. In this respect, one should be interested in analysing their activities for diversification and hence these details are discussed with the authorities concerned and the details are presented in Table 12. 
Table 12 outlined that there were four principal activities are aimed to perform in future with the approval of the authorities concerned. One of the activities for diversification is becoming a dealer of Arasu Cement. It is one of the good efforts because most of the cement requirements were drawn from the nearby cities like Mettupalayam and Coimbatore and hence the NCMS can establish such a business which will be of promising in nature due to the growing demand for construction activity in Nilgiris. But further expansion of city should not create ecological and environmental issues and hence the same should be subjected to environmental scrutiny.

The second proposal available with NCMs is establishment of Indian Oil Corporation petrol bunk. This is also a good effort. Because of the availability of land with NCMS, it can operate a petrol bunk on the lines of Chinthamani Cooperative Stores in Coimbatore city. Increasing urbanization and vehicular traffic, a good demand exists among the two and four wheelers if the produce is offered at offer price and quality enforcement to convince the consumers.

The establishment of new branches for fulfilling or extending the pledge loan provision to the farm and rural households is also an ideal proposal and hence the NCMS can explore the demand driven environments so as to gain considerable revenue. It is learnt that the NCMS has identified the place at Ooty and Coonoor of Nilgiris District with safety vault for pledge loan facility to the farmers. This will really contribute to the agricultural operations planned by the farm households of Nilgiris.

To promote the fertilizer sales, the Fertilizer Distribution Centres were also aimed at and different points have been identified by the Managing Director of NCMS. The potential places for establishing the fertilizer distribution centres were found to be Pandalur, Thenaducumbai, SolurMattam and Nedugula. These areas have been identified to tap the potential villages in which farming operations were intensive and hence the inputs like fertilizer will have a much demand and hence NCMS could reap the profit from fertilizer and other input sale.

Traditionally Agricultural Marketing activities are fully grasped by the whole set of intermediaries from harvest zone to the consuming end and hence the producers placed with dismal share of profit and the intermediaries are gaining much. To alleviate this process, cooperative marketing was practiced by a progressive farmer, Auri Gowder. Nilgiris Cooperative Marketing Society is a special type of marketing society established during pre-independence and currently involved with diversification of various activities and extending useful services to the farm households who are cultivating the hill vegetables at Ooty. Main activities by which the farmers are getting benefitted were direct procurement of vegetables by NCMS and selling the same to the consumers and the traders directly. Besides, the farmers are provided with inputs like fertilizer, pesticides and seeds for taking up vegetable cultivation. Pledge loan facility is also extended to the farming community to meet the immediate cash needs for taking up the cultivation practices. On analysing the profit scenario, the society is capable of generating a net profit of Rs 234 lakhs per annum on an average. To enhance the return further, futuristic programs are also aimed at and are under consideration by the Government.

\section{References}

Government of India (1976) "Report on National Commission on Agriculture - 
Volume 12" (Ministry of Agriculture and Irrigation: New Delhi) p. 122.

Government of Tamil Nadu (2018) "Horticultural Statistics at a Glance" (Department of Horticulture and Plantation Crops: Chennai)

Manalili, N.M., (2003) "Linking Farmers to Markets through Cooperatives Vegetable Supply Chain Redesign options for Kapatagan, Philippines", pp. 01-22

Maxime, A., D. Rousseliere and S. Julien (2014) "Agricultural Marketing
Cooperatives with Direct Selling: A Cooperative Non Crop Game" (http://www.gate.cnrs.fr.) working papers.

Vidhyavathi, A., C. Sekhar and K. Uma (2012) "Supply Chain Issues and its Implications on Supermarket Developments in Asia - A Paradigm to Tamil Nadu" (Proceedings of the National Seminar on Agribusiness Potential of Tamil Nadu, (Indian Society of Agricultural Marketing: Nagpur) pp. 57-74.

\section{How to cite this article:}

Sekhar, C., A. Vidhyavathi and Divakaran, A. 2019. Vegetable Marketing by Nilgiris Cooperative Marketing Society - A Paradigm. Int.J.Curr.Microbiol.App.Sci. 8(08): 1361-1373. doi: https://doi.org/10.20546/ijcmas.2019.808.159 